\title{
SEDIMENTOLOGICAL OBSERVATIONS ON THE EARLY CRETACEOUS SEDIMENTS IN EASTERN PARTS OF THE NÛGSSUAQ EMBAYMENT
}

\author{
E. J. Schiener
}

\begin{abstract}
The early structural evolution of the embayment is evaluated by interpretation of sedimentary features at the contact between Precambrian basement and the overlying sediments and by interpreting vertical facies relationships within the Cretaceous sediments.
\end{abstract}

\section{Introduction}

In the Nûgssuaq embayment the unconformity between the Precambrian basement rocks and the Mesozoic cover is exposed only in a few localities. The coastal section to the east of the Ikorfat promontory on Nûgssuaq together with the landward slopes provide sufficient exposure to allow a reconstruction of the depositional conditions for the sediments (figs 24 $\& 25)$. However, the situation of key exposures does not permit the observation of a continuous profile from the basal unconformity through to the overlying basalts. Basement-cover contacts are limited to low coastal cliff sections and isolated localities further inland; they are always separated horizontally and vertically from the lowest parts of the nearest stream sections that expose continuous vertical sequences through to the base of the volcanics.

Additional difficulties are introduced by a number of young coast parallel faults; generally they are normal slip faults, but there is at least one possible major oblique slip fault present. Owing to the small throws, distinctive lithological units are readily picked up again in the individual fault blocks.

At the time of the field investigations from 1972 to 1974 the biostratigraphic position of the sediments was based on Koch (1964), who assumed an unconformity between the Lower Cretaceous Kome Formation and the younger Atane Formation. Palynological investigations of Croxton (1976; personal communication) indicate that the top of the Cretaceous sedimentary section has an Upper Albian or Cenomanian age. Evidence for an unconformity within the section is not convincing with the exception of one locality at Talerua (fig. 24); it is therefore assumed here that the greater part of the sediments were deposited during the Early Cretaceous. 


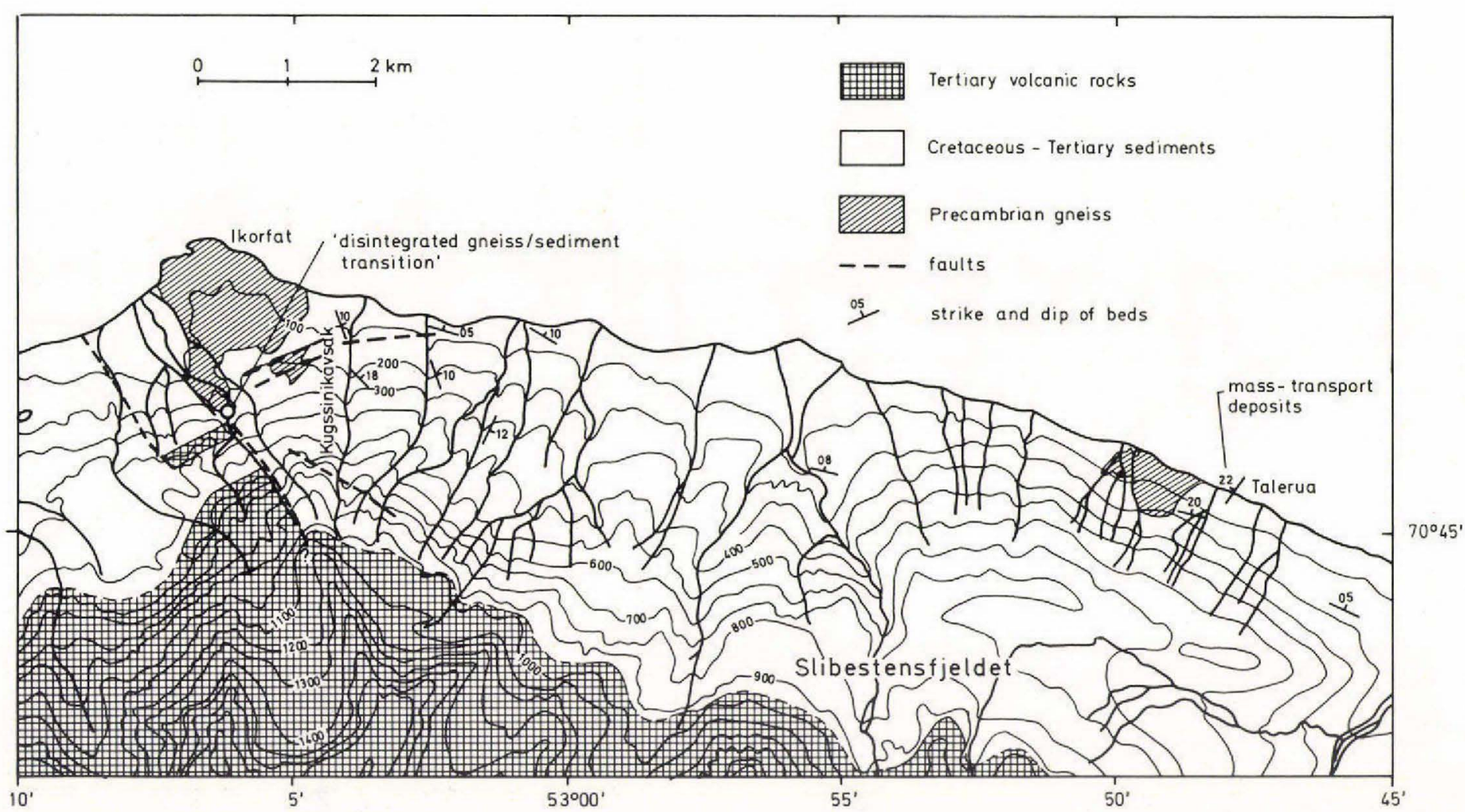

Fig. 24. Diagrammatic geological map of the coastal area between Ikorfat promontory and Slibestensfjeldet on the north coast of Nûgssuaq, West Greenland. 
Fig. 25. Diagrammatic map of coastal area west of the boundary fault at Kûk, north coast of Nûgssuaq.

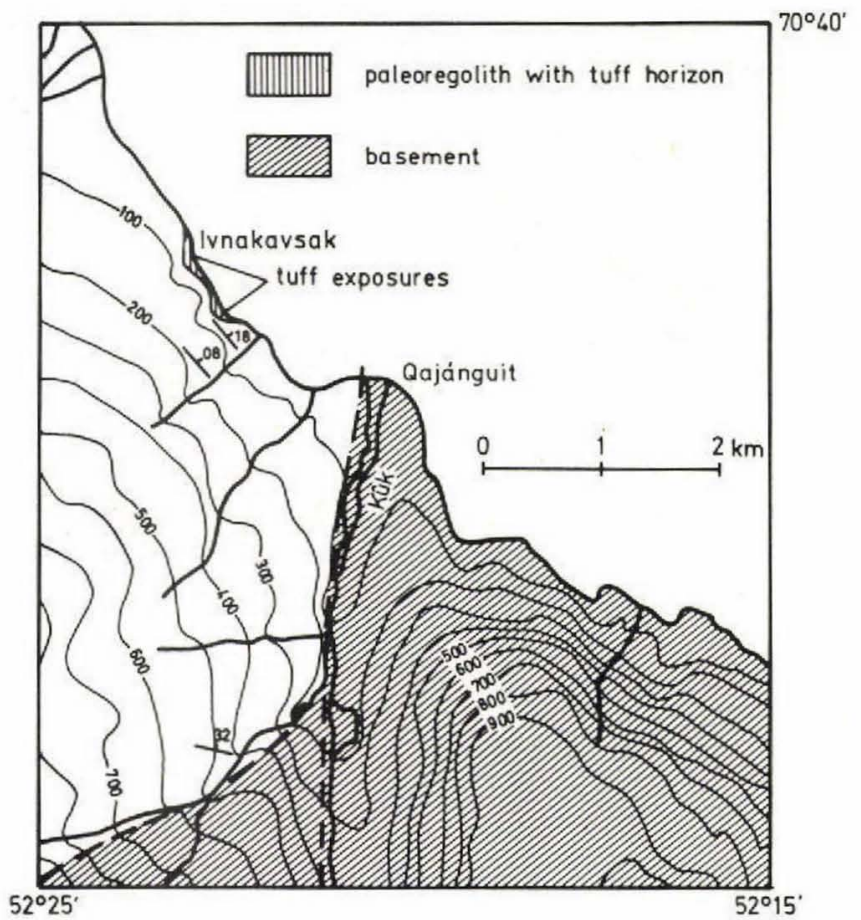

Regional relief on the basement surface is considerable, rising from sea level to $1800 \mathrm{~m}$ within 5-6 km inland from the coast. In some of the coastal outcrops, however, relief differences appear to be weak locally.

The nature of the unconformity is far from uniform in the region under consideration. Rosenkrantz \& Pulvertaft (1969) report deeply weathered gneiss with the weathered zone up to $35 \mathrm{~m}$ in thickness. A commonly observable feature is a thinner (maximum 4-6 m thick) zone of disintegration, without development of chemically altered horizons; where the basal sediments consist of sandstone, the transition is difficult to pinpoint (Ikorfat). Similarly well concealed is the intercalation of a thin rhyolitic tuff deposit between deeply weathered gneiss and the earliest deposits of the normal facies of the Cretaceous sediments at Ivnakavsak (fig. 25). A further variation is flanking a basement knoll; the overlying sediments show indications of a mass-transport deposit intercalated between fresh gneiss and the normal sedimentary facies (east of Talerua). In these exposures at least two angular discordances exist between the lower, differently developed sediments and the 'normal' facies of the Cretaceous sediments (fig. 26).

In the following sections individual facies elements and their specific characteristics are described and related to the development of the sedimentary basin.

\section{Contact of Precambrian basement and Mesozoic sediments}

At least three different types of sedimentary development can be described from this zone exposed in the eastern parts of the north coast of Nûgssuaq. 


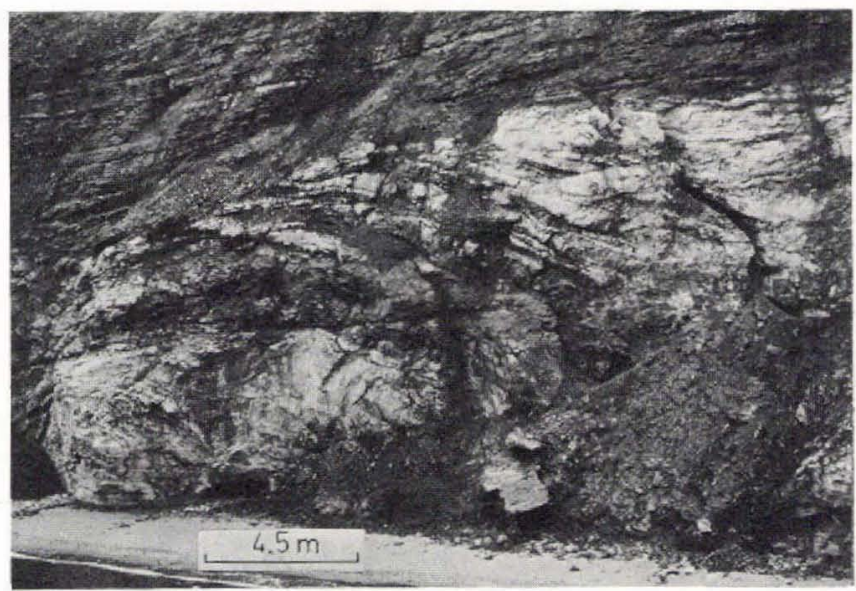

Fig. 26. Angular disconformity between sediments directly overlying basement and the normally developed Cretaceous sediments, Talerua.

\section{Disintegrated gneiss transition}

The fresh leucocratic gneiss is strongly foliated with near horizontal layering. Quartz veins are very common. The transition from unweathered gneiss to the reworked weathered zone is very indistinct (fig. 27) and only some distance above the actual base does the reworking become recognizable by more continuous lenses and bands of angular vein quartz. There is no colour change detectable.

The sedimentary nature of the overlying deposits only becomes obvious from the first dark siltstone band, $20-30 \mathrm{~cm}$ thick, with abundant outsize (millimetre-sized) quartz and feldspar clasts. The dark colour of the siltstone band is caused by finely dispersed coaly matter.

In the subsequent lenticular bedded and flaggy siltstone a strong size discrepancy between the dominating well and thinly bedded siltstone and the flasers of coarse quartzose sandstone continues. The change to the overlying very coarse, in parts pebbly sandstone is abrupt. Bedding is indistinct, with irregularly distributed lenses of pebble sized vein quartz and gneiss fragments; coaly matter is present, but has no colouring effect. The overall impression is very similar to the 'disintegrated' gneiss and is best described as 'granite wash'. The majority of feldspars are relatively fresh; micas are not common.

A second shaly silty band again around $30 \mathrm{~cm}$ thick overlies the more massive 'granite wash' bed. It is followed upwards by fine flaggy sandstones, rich in dispersed organic debris and with concentrations of micas and coaly matter on the partings. There is an upward transition with increasingly greater proportions of dark silty shaly material to a third shale band. In this hardly any outsize clasts are found. The lower parts of the low angle cross laminated sandstones that overlie the shale horizon are well and evenly bedded. Shaly partings produce a flaggy appearance. Towards the top of this unit coarser sandstone beds appear. They are faintly graded and lack the lamination of the underlying laminated sandstone, in which they cause slight load deformation. 
Fig. 27. Contact between gneiss-basement and overlying sediments at Ikorfat.

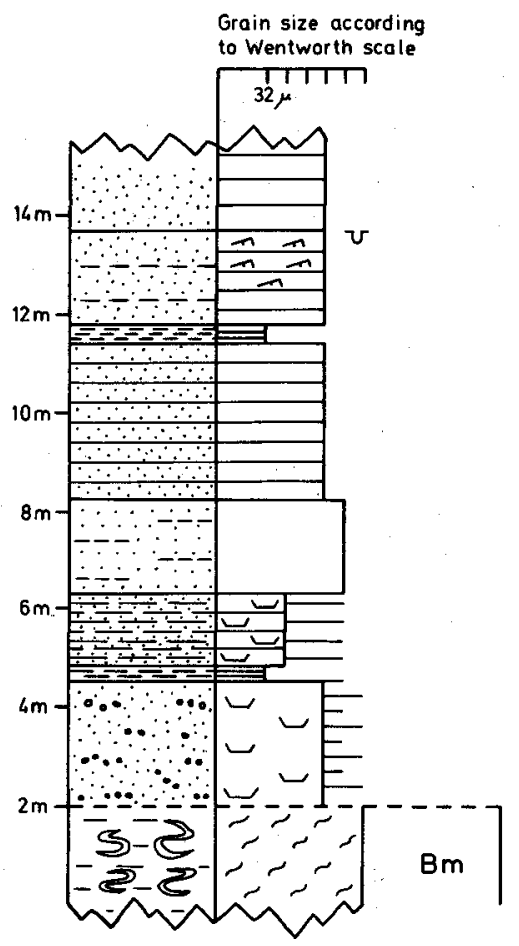

\section{Interpretation}

The basal sediments were deposited under predominantly low energy conditions (absence of cross-bedding) without influx of transported material. Reworking of the existing regolith by current or wave action did not penetrate to the unweathered gneiss. The lack of clay sized weathering products can either be ascribed to gentle winnowing or may be related to chemical conditions. The absence of both ferric and ferrous colorations below the first concentration of organic matter in the carbonaceous siltstone band would indicate acid environment in which most mica minerals are unstable (Füchtbauer \& Müller, 1970).

Upwards the development of lenticular bedded siltstone and thinly bedded, flaggy, medium grained sandstone indicates continuous shallow water environment; the intercalations of coarser sands could be produced by catastrophic pulses like storms or floods providing increased influx of material. That deposition of the 'granite wash' was quick is indicated by the slight loading produced in the upper laminated fine sandstone.

The absence of faunal elements leaves the actual environment of deposition open to speculation. A prograding shore environment, either marine or lacustrine, might be considered. 


\section{Rhyolitic tuff horizon}

In the coastal cliffs at Ivnakavsak (fig. 32) the Precambrian gneiss is covered by a 5-8 metres thick paleoregolith consisting of both reworked debris and in situ paleosoil. Both reworked material and paleosoils show irregularly distributed patches with red oxidation colours in the prevailing grey to fawn coloured rocks with abundant kaolonitic matrix.

Above the paleoregolith a thin rhyolitic tuff horizon is continuously exposed for a horizontal distance of approximately $400 \mathrm{~m}$. The deposit is normally $2-3 \mathrm{~m}$ thick, with maximum thickness observed around $9 \mathrm{~m}$ (figs 28 \& 29). The character of the horizon varies between dense massive and crudely bedded material reminiscent of waterlaid tuff. Macroscopically the deposit is characterized by quartz phenocrysts together with pyrite filled pumice fragments in a matrix of kaolonitized shards. Topmost parts of both the dense and the bedded varieties become increasingly contaminated by carbonaceous wisps and are finally covered by a thin $(15 \mathrm{~cm})$ impure coal seam. Above the coal seam follow the arkosic sandstones alternating with carbonaceous shales that constitute the 'normal' Early Cretaceous facies.

\section{Interpretation}

The localized occurrence of a deposit presumably originating from an explosive volcanic phase appears to be contradictory to the normally very widely distributed tuffs from the geological record. A reason for this could be the limited exposure of the contact basement-cover rocks, a second explanation might be the limited conditions for preserva-

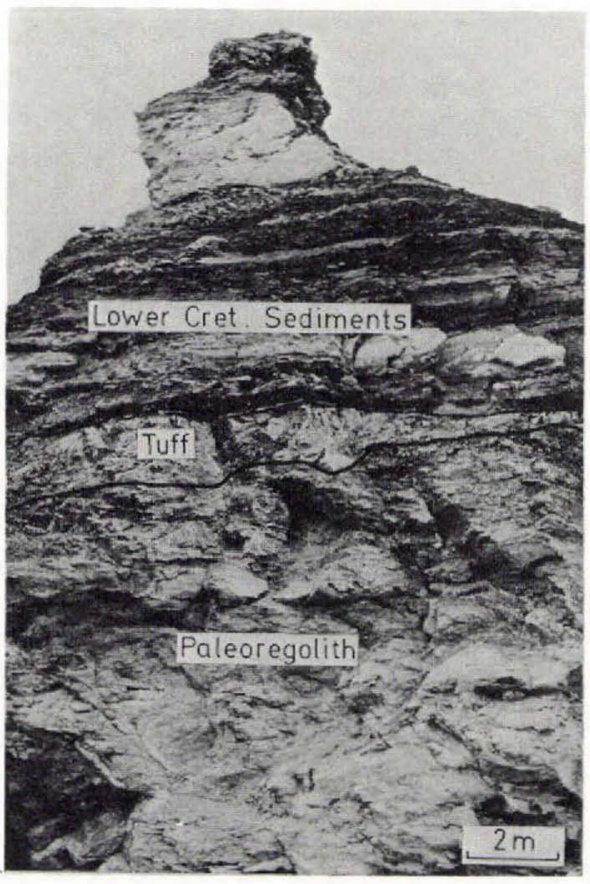

Fig. 28. Intercalation of tuff horizon between pre- or early Cretaceous paleoregolith and early Cretaceous Kome facies sediments, Ivnakavsak. 


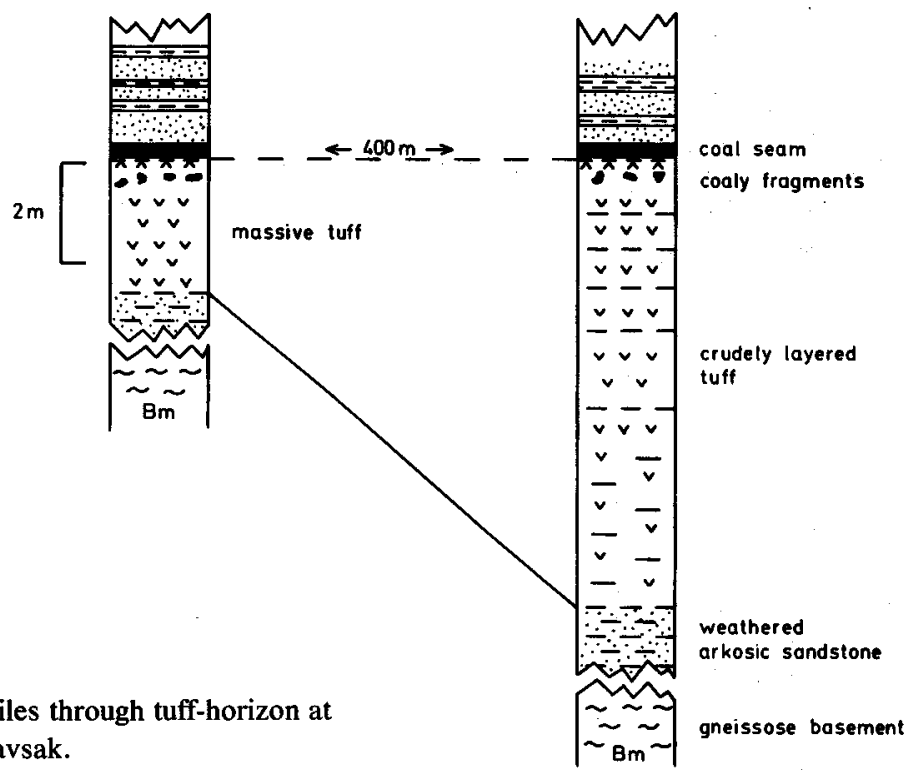

tion of a thin and chemically unstable ash deposit. However, the frequent and widespread occurrence of fragments of pisolites and other silicified ?tuffs in the Early Cretaceous sandstones (Schiener, 1974) might indicate a much wider distribution than has been observed.

From the accessible exposures it is equally difficult to determine the environment as well as the mechanism of deposition. The bedded appearance and the poorly developed sorting suggest that the tuff originated as normal fall-out from a single phase of explosive volcanic activity. Concentration of pumice in top parts would indicate aqueous environment, which seems to be substantiated by the admixture of carbonaceous material, culminating in the overlying vitritic coal seam. Deposition in a shallow waterlogged depression with quickly accumulating cover of organic matter might be the reason for the local preservation. The presence of well crystallized kaolinite 'books' and the absence of carbonate in the tuff indicate acid fresh water environment (Tröger, 1969).

\section{Mass-transport deposits below 'normal' facies}

Although the gneiss base to these deposits is not exposed, it can be inferred as being close, as the nearest gneiss outcrop is less than $100 \mathrm{~m}$ away at Talerua.

The exposed deposit has a thickness of 5-6 metres (fig. 30). It consists of a lower sharpstone conglomerate (Pettijohn, 1975) containing imbricated gneiss slabs in a coarse sand sized matrix. The matrix consists exclusively of gneiss-derived vein quartz, centimetre sized gneiss fragments and conspicuously large feldspars (fig. 31). Cementation is very thorough. The slabs reach $15-20 \mathrm{~cm}$ along their long axes and are $3-4 \mathrm{~cm}$ thick; they consist of a darker, mica rich rock, characteristic of the dark bands occurring in the banded 


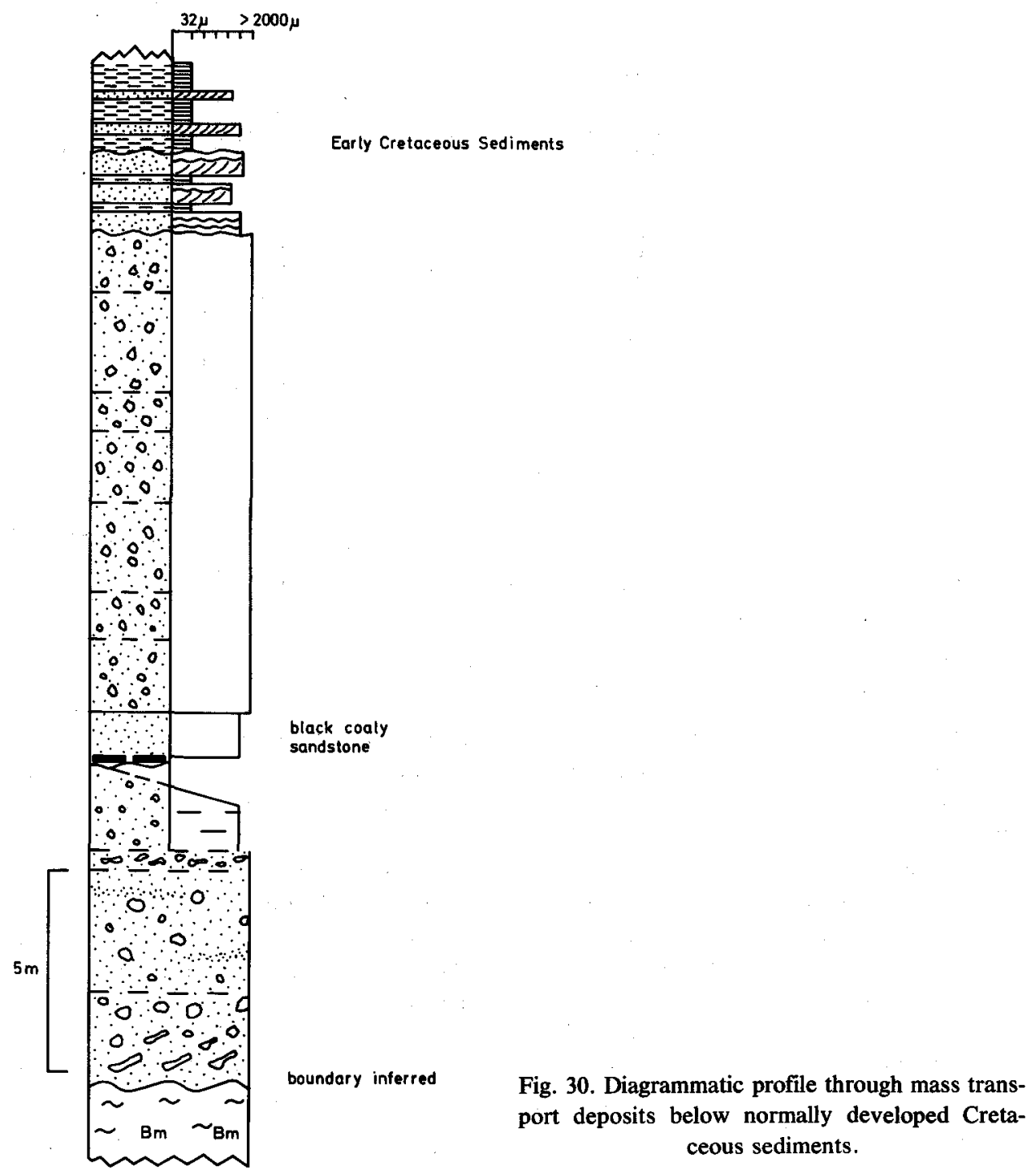

gneiss described by Henderson \& Pulvertaft (1967). Towards the top there are more equidimensional fragments in a size range from $10-15 \mathrm{~cm}$ across. The composition of the fragments is gradually changing with light coloured and non-foliated gneiss becoming more abundant. Apart from the lowest parts with imbricated components the deposit is massive and shows only indistinct layering. Above a second sharpstone conglomerate with imbricated slabs the gneiss-derived debris becomes crudely bedded and finer grained with a high proportion of kaolinitic matrix. 


\section{Interpretation}

This facies of the basal deposits bears strong resemblance to material deposited from mass transport like fanglomerates or pebbly mudstones (Crowell, 1957). The difference to the normal lithologies lies in the near complete absence of fine grained, muddy material in the matrix. The matrix is sand sized and forms the supporting medium for the cobbles and boulders of gneiss.

The imbricated base indicates a very high flow regime with abundant bed load. It could correspond to a channel deposit. The gradual transition upwards into the chaotic mixture of coarse sand with large outsize cobbles is most likely interpreted as a change to a slurry flow, where the absence of fine material in the matrix may be an original feature (type of weathering). The slurry flow presumably represents the slower fraction of the total mobilized mass. The available water was able to drain quickly from the coarse bulk, forming the high bed load channel deposit at the base. Two depositional cycles are preserved.

Disregarding the speculation over a possible transport mechanism, the deposit clearly shows that high energy flow processes also were active during the submergence of the basement. Since most basal parts of the 'normal' Cretaceous sediments indicate low relief energy, it might be assumed that a period with active faulting preceded the more tranquil phase of 'normal' deposition. The resulting localized rejuvenation of the relief initiated the redistribution of the pre-Cretaceous regolith.

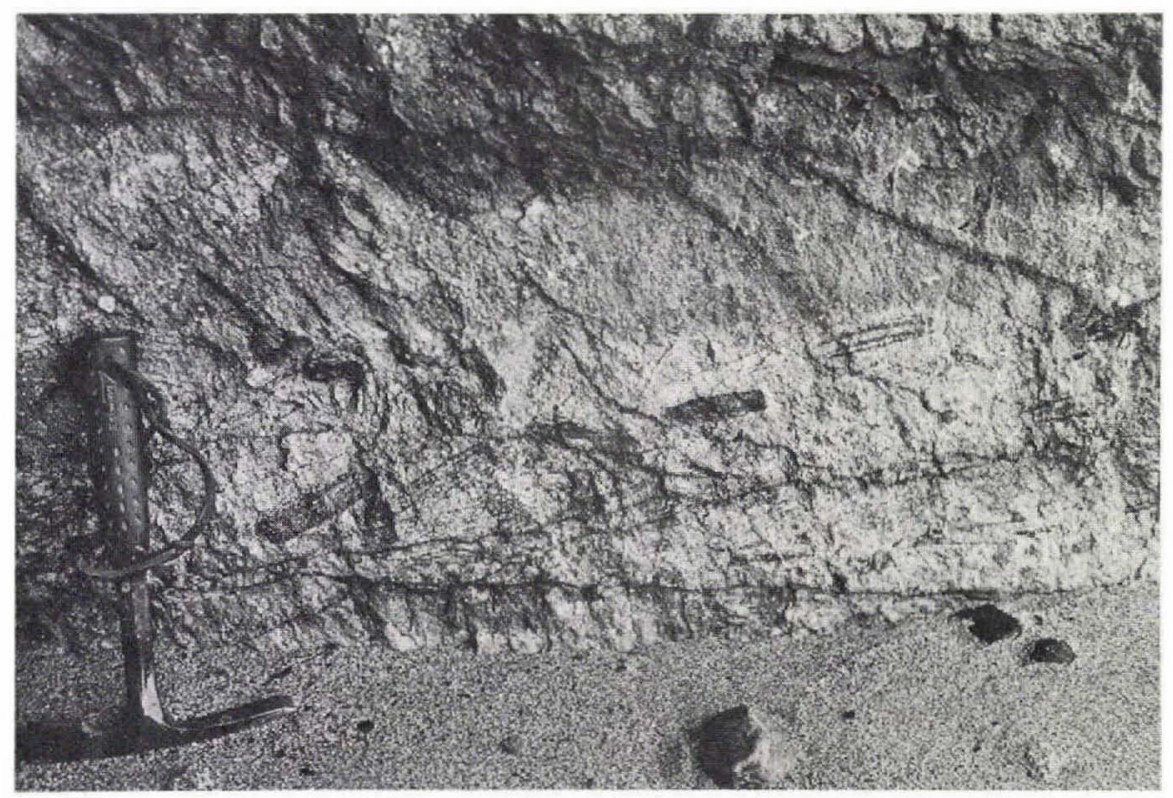

Fig. 31. Mass transport deposits below normally developed Cretaceous sediments. 


\section{Sedimentary facies of the Cretaceous sediments}

The Early Cretaceous sediments on north-eastern Nûgssuaq reach from sea level to around $880 \mathrm{~m}$ altitude. The true thickness is difficult to ascertain owing to the occurrence of the repeated younger faulting, but should not be much less than $800 \mathrm{~m}$.

The sequence can be subdivided into four major facies types (fig. 32), which include:

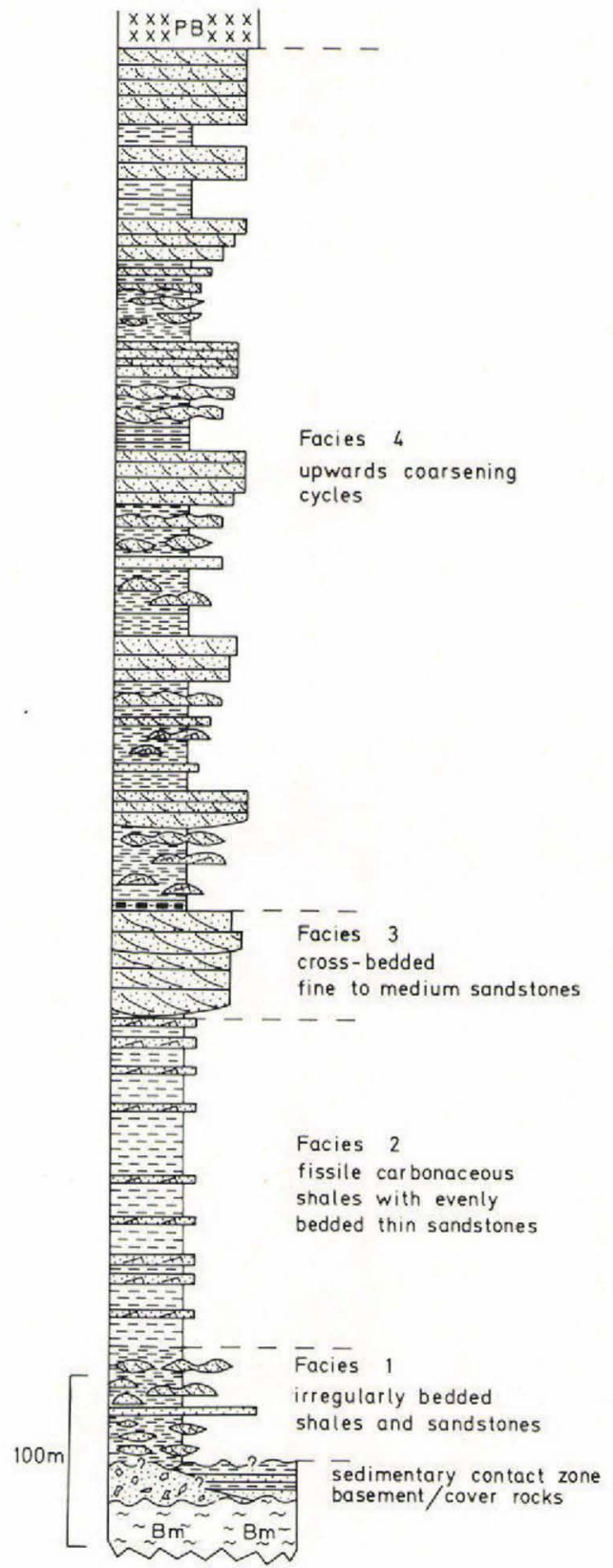

Fig. 32. Diagrammatic composite profile east of Ikorfat (thickness of sandstone beds not to scale). 


\section{Facies 1 (Irregularly bedded, alternating shales and sandstones)}

In the region east of Ikorfat the basal facies is developed over recognizable basement highs like the Ikorfat promontory, around Qaerssuarsuk and west of Kûk (figs 24 \&25).

Facies 1 consists of irregularly bedded discontinuous coarse sandstones with black silty shaly intercalations. Thin coal seams and seamlets are found locally. The thickness of this facies varies, but normally does not exceed $50-70 \mathrm{~m}$. The white to fawn coloured sandstones are frequently arranged as stacked channels (Brown, 1975) on a small scale (between 6-10 $\mathrm{m}$ horizontal extent, width-depth ratios around 13 in the surrounding shales). More continuous sandstone units are relatively thin $(20-30 \mathrm{~cm})$, with abundant pebbles and granules of poorly rounded vein quartz in discontinuous layers. Irregular trough cross-bedding, generally with low angle sets, is the dominant sedimentary structure (fig. 33).

The sand is coarse grained and in general poorly sorted. Angular quartz, feldspar and the occurrence of compound quartz-feldspar aggregates is suggestive of a derivation from a gneiss-dominated terrain. The granite wash nature is well preserved and indicates short transport. Pore space is frequently occupied by kaolonitic degradation products of the feldspars.

The siltstones-shales are very carbonaceous and micaceous. Outsize quartz and feldspar clasts are very common and occur dispersed as well as in small flasers.

Pyrite is very common to both the main lithologies; single concretions up to $10 \mathrm{~cm}$ in diameter have been observed in sandstones. In the siltstones-shales pyrite also occurs in concretions, but is normally dispersed as millimetre sized framboidal aggretates.

\section{Facies 2 (Fissile carbonaceous shales with evenly bedded, thin sandstones)}

This facies has its maximum development just to the east of Ikorfat and presumably interfingers at the base both eastwards and westwards with equivalents of facies 1 . The

Fig. 33. Facies with stacked channels, Slibestensfjeldet.

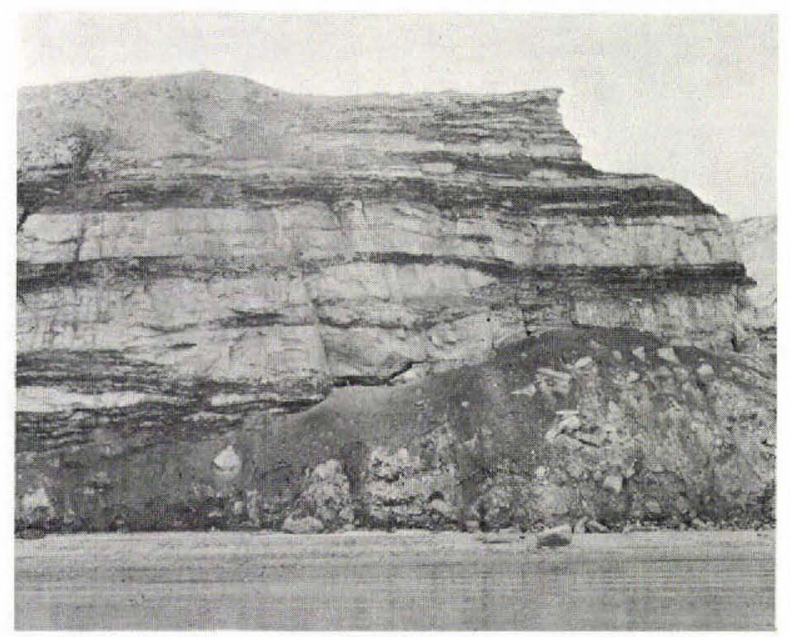


total thickness is close to $200 \mathrm{~m}$. It is characterized by very evenly bedded and fissile dark shale with intercalations of thin, very continuous bands of siltstone and fine sandstone. The thickness of the bands rarely exceeds $5-10 \mathrm{~cm}$, but single bands up to $50 \mathrm{~cm}$ do occur. The vertical distance between individual sandstone bands varies, but is normally in the range of at least $3-5 \mathrm{~m}$, although occasionally denser clustering is found, especially towards the top $70 \mathrm{~m}$.

The fine sandstones have very slightly irregular bases with occasionally shallow sole marks, show faint size grading in the lower parts and parallel laminations in central parts, whereas the top 1-2 cm are cross-laminated. The very low angle cross-lamination is accentuated by carbonaceous plant debris on foreset laminae. Small scour-and-fill structures are occasionally found. In some beds irregular burrows of the 'siphonites-association' are preserved. Bed surfaces show a variety of structures, predominantly very shallow ripple marks (wavelength $12-15 \mathrm{~cm}$, ripple height $0.5-1 \mathrm{~cm}$ ). Mica flakes and plant debris are concentrated in the depressions between ripples. Although the ripple marks show interference between two or three directions, a dominating $120^{\circ}-140^{\circ}$ alignment is clearly recognizable. On some surfaces shallow toolmarks and narrow, polygonal mudcracks are found. The toolmarks are frequently oriented at right angles to the aligned ripplemarks. Very characteristic is the reddish brown oxidation colour of some beds which contrasts with the more frequent grey-green coloration. The fine sandstones are dense and well cemented by carbonate.

\section{Facies 3 (Cross-bedded, fine to medium sandstones)}

The transition to facies 3 is gradual. Towards the top of facies 2 single sandstone units appear, which in contrast to the very evenly bedded thin sands are cross-bedded with slightly downcutting bases and even tops. Single foresets are emphasized by a granule layer of subangular to rounded quartz. Cross-bedding is of both planar and festoon type with high depositional angles.

Some of these transitional cross-bedded sand bodies are lens shaped; others are horizontally continuous. The shaly intercalations between sandstones become gradually thinner.

The clean sandstone facies begins rather abruptly with a downcutting base, above a final, thicker interval of fissile shale (fig. 34). Going up through the sequence bedding planes are straight and parallel, apart from occasional major scours with channel like depressions at their bases.

The yellowish weathering sandstones have very uniform grain size distributions, the bulk being of fine to medium sand with coarser material on foreset laminae or in horizontal bands of small thickness (centimetre range). Shaly or carbonaceous components are almost completely absent; only towards the top are details of lamination emphasized by carbonaceous-shaly laminae. Cementation by carbonate is very thorough.

\section{Facies 4 (Coarsening upwards cycles of limited thickness)}

Facies 4 can be best described as consisting of a condensed version of a combination of facies 1 to 3, essentially as an upward coarsening cycle. Dark fissile shales-siltstones abruptly overlie the sandstones of facies 3 . A shaly leaf-coal horizon of approximately 2 $m$ thickness is an excellent marker for the base of this facies development. 


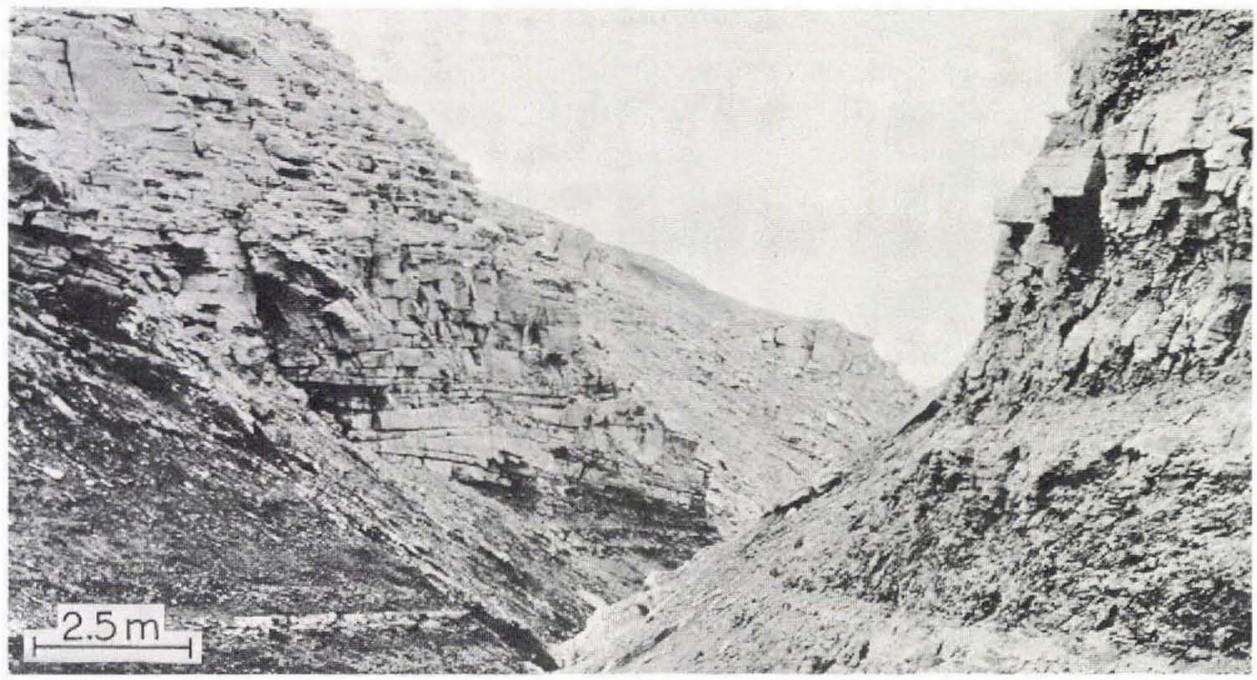

Fig. 34. Contact between facies 2 and facies 3 in the Kugssinikavsak gully.

In going upwards gradually the number of sandy beds increases concurrently with an increase in thickness of the individual beds from around $5 \mathrm{~cm}$ to around $30 \mathrm{~cm}$. In contrast to the underlying sandstone of facies 3 , the sands are coarser, poorly cemented and contain abundant carbonaceous detritus dispersed within the matrix as well as concentrated on laminae. The vertical tripartition in a massive, slightly graded basal part, a parallel laminated central part and cross-laminated top part is retained in more continuous beds whereas in some parts lenticular bedding occurs. This intermediate sequence is then followed abruptly by an 8-10 $\mathrm{m}$ thick sandstone unit without major participation of carbonaceous and/or shaly material. The sandstone is coarse, frequently pebbly, strongly cross-bedded with both planar and trough cross-bedding.

At least four normal developments of these upwards coarsening cycles, each approximately $20-30 \mathrm{~m}$ thick, are recognizable in the upper parts of the sections. The cycles towards the top of the sequence are characterized by the occurrence of rusty brown cementation horizons formed of ferrous oxide-hydrates. They occur either as centimetre thick crusts, cementing loosely packed sand on bedding surfaces or as irregular bands subparallel to or cross-cutting bedding planes.

In some of the pebbly beds, reworked fragments of these ferrous cementation horizons indicate syndepositional formation. The position of a conglomeratic development, topping the sedimentary sequence just below the Tertiary pillow breccias is too uncertain with regard to its exact stratigraphic position. It is provisionally excluded from the Early Cretaceous section; a very similar development is also found in the same position west of the Ikorfat fault, just a short distance below the volcanic rocks on top of the Late Cretaceous sequence there. It might represent the regression surface at the base of the Tertiary. 


\section{Interpretation}

The absence of a marine fauna does not allow a closer zonation of the sediments, but an Albian age has been established for lower parts of the section and in the uninterrupted sequence a Late Albian-Cenomanian age for a horizon from the uppermost part is indicated by palynological studies. Preparations from the lowest strata have so far yielded indeterminate palynological assemblages with poor preservation (Croxton, personal communication, 1976).

For a more definite determination of the depositional environment the content of biological indicators is insufficient. However, the occurrence of dinoflagellates together with burrows distributed through the lower parts of the succession (facies 2) are indicative of some marine influence. Detailed sedimentological analysis requires additional studies of the association of sedimentary structures and their sequence. Similarly granulometric and petrographic investigations would have be to applied. For the present initial interpretation of the sedimentary sequence and its implication for the development of the basin the field data have to suffice.

Facies 1 is characterized by well defined separation of size fractions into one deposited from upper flow regime (Harms \& Fahnestock, 1965) bed load (sand) and one deposited predominantly from suspension under tranquil conditions (shale). The bed load deposits display clearly channel characteristics, with preferential compaction of the underlying overbank shale leading to the development of stacked channels. This implies prevalence of a very low energy environment with minimal relief, where compaction differences were sufficient to create the necessary relief to form channels for a subsequent depositional process. Lateral migration of channels as well as crevasse splay led to the irregularly bedded appearance of many of the sandstone units. The few thin and more continuous sandstone beds would represent larger scale sheet flood deposits. There are no signs of prolonged reworking in the sediments, which implies rapid deposition and/or deposition beyond the reach of waves and currents.

The composition of the sand betrays its derivation from a gneiss terrain; the relative freshness of the feldspars indicates rapid transport from the source area. Micas together with the fine fraction were removed from the bulk, owing to their different hydraulic behaviour and deposited further downslope as separate fraction. The greyish fawn colours of the sandstones, the presence of pyrite together with thin coal seamlets rich in vitrinite indicates that the depositional environment was deficient in oxygen.

A subsiding lower alluvial plain is envisaged as the depositional environment. The abundance of coarse detrital material in a fluviatile system would downdip lead to the development of a constructive deltaic shoreline (Selley, 1970) with resulting differentiation of the non-framework (interdistributary) facies.

Facies 2 is interpreted as the consequent development of facies 1. The thick laminated carbonaceous shales-siltstones represent the downslope or lateral deposits in a low energy environment of the sand-dominated 'lag' sediments of the alluvial plain. The very evenly bedded thin sandstones with their typical vertical sequence of sedimentary structures are similarly related. They were deposited downslope during major flood phases when the 
occasionally preserved sheet sands mentioned under facies 1 were formed updip. The faint resemblance to distal turbidites is seen as substantiation of transport of fine sand sized material in turbulent suspension.

The red oxidation colour of many of the sandstone beds apparently contradicts the interpretation of a subaqueous reducing environment; in most cases it can be seen that the coloration is caused by weathering of the iron carbonate cement and only extends approximately 5-10 $\mathrm{mm}$ into the fresh rock.

The interpreted facies relationship implies a transgressive trend, presumably caused by continuing subsidence. Additional evidence is provided by the occurrence of infrequently observed dinoflagellate cysts (Croxton, personal communication, 1976), burrows of the siphonites association and the abundance of carbonate cement in the sandstones.

Towards the top parts of facies 2 a gradual increase in the frequency of occurrence and in thickness of sand units is observable. This can be interpreted as the initiation of the reversal of the basal transgressive trend. Slowing down of the subsidence presumably led to the gradual infilling, which allowed the advance of coarser sediments over the shalessiltstones.

Facies characteristics would indicate lagoonal environment; alternatively a subaqueous delta platform development could be envisaged. In the latter case protective barriers towards the top delta front would have to be postulated.

Facies 3 indicates a return to high energy depositional environment and thus may represent the culmination of the regressive trend indicated in top parts of facies 2 . Sedimentary features like low angle cross-bedding of unimodal dip within laterally persistent, evenly bedded sandstones, the moderate to good sorting, absence of carbonaceous debris, micas and clays within the sandstones, and the presence of occasional channels are consistent with the development of a prograding sandy shoreline (Masters, 1967). This interpretation would reasonably well fit a consistent spatial evolution of the sedimentary environments, resulting in a transgressive-regressive couplet of considerable thickness.

Facies 4 . The repetition of upwards coarsening sequences of limited thickness (10-30 m) in this facies is primarily an indication of more rapidly changing depositional conditions.

Upwards coarsening sequences are generally recognized as being genetically related to prograding shorelines. The detailed facies relationships within described offlap sequences from deltaic environments (Oomkens, 1967; Allen, 1965; van Veen, 1971; Visher, 1965) are strongly dependent on the overall depositional framework, which has not yet been determined to any detail in the embayment. A more thorough discussion of the interpretative possibilities would go beyond the framework of this account.

\section{Conclusions}

Rosenkrantz \& Pulvertaft (1969) described the Early Cretaceous sediments on the north coast of Nûgssuaq as limnic, without giving facts or observations other than the absence of a marine fauna.

Thick non-marine clastic sequences are known from post-orogenic molasse type basins in developing foredeeps as well as from intramontane basins. The latter are commonly 
related to major structural features associated with tensional faulting and lead to the formation of horst and graben structures, features that have been described by Henderson (1973) from West Greenland.

The facies developments as described above would indicate the initation of a developing depression within the embayment by pronounced crustal movements earlier than the mid Early Cretaceous. The volcanic event leading to the deposition of the acid tuff is connected to these movements. Resulting relief differences caused the rapid redistribution of the thick, presumably pre-Mesozoic regolith in non-marine environments. Subsequent movements consisted of a gradual downwarping with redistribution and reworking of regolithic material by drainage systems (facies 1 and 2). Renewed acceleration of baselevel changes began with the onset of facies 3 , which found its culmination in the more rapid cyclic repetitions of facies 4 .

The indications of marine influence during the deposition of the described sediments are inconclusive; the sparse organic traces (dinoflagellates and burrows) could equally well have originated in a large non-marine basin. The subsequent tectonic development of the cratonic margin in the Late Cretaceous-Early Tertiary, when tensional block faulting concurrent with increasing marine influence, led to greater facies differentiation, tends to suggest in analogy a similar marginal situation for the described part of the embayment.

\section{Acknowledgement}

Atlantic Richfield geologists Don Ehman and Jim Wise pointed out to the author the presence of the tuff horizon at Ivnakavsak. Their co-operation and friendly assistance is greatly appreciated.

\section{References}

Allen, J. R. L. 1965: Late Quaternary Niger delta and adjacent areas: sedimentary environments and lithofacies. Bull. Am. Assoc. Petrol. Geol. 49, 547-600.

Brown, L. F. 1975: Role of sediment compaction in determining geometry and distribution of fluvial and deltaic sandstones. In Developments in Sedimentology $18 \mathrm{~A}, \mathrm{G}$. V. Chilingarian \& K. H. Wolf (edit.) Compaction of coarse-grained sediments, 1, 247-292. Amsterdam, Oxford, New York: Elsevier.

Crowell, J. C. 1957: Origin of pebbly mudstones. Bull. geol. Soc. Am. 68, 993-1010.

Croxton, C. A. 1976: Sampling of measured sections for palynological and other investigations between $69^{\circ} \mathrm{N}$ and $72^{\circ} \mathrm{N}$, central West Greenland. Rapp. Grønlands geol. Unders. 80, 36-39.

Füchtbauer, H. \& Müller, G. 1970: Sedimente und Sedimentgesteine, Stuttgart: Schweizerbart'sche Verlagsbuchhandlung.

Harms, J. C. \& Fahnestock, R. K. 1965: Stratification, bed forms and flow phenomena (with examples from the Rio Grande). Spec. Publ. Soc. Econ. Palaeont. Min. 12, 84-115.

Henderson, G. 1973: The geological setting of the West Greenland basin in the Baffin Bay region. Pap. geol. Surv. Can. 71-23, 521-544.

Henderson, G. \& Pulvertaft, T. C. R. 1967: The stratigraphy and structure of the Precambrian rocks of the Umanak area, West Greenland. Meddr dansk geol. Foren. 17, 1-20.

Koch, B. E. 1964: Review of fossil floras and nonmarine deposits of West Greenland. Bull. geol. Soc. Amer. 75, 535-548. 
Masters, C. D. 1967: Use of sedimentary structures in determination of depositional environments, Mesaverde Formation, Williams Fork Mountains, Colorado. Bull. Am. Assoc. Petrol. Geol. 51, 2033-2043.

Oomkens, E. 1967: Depositional sequences and sand distribution in a deltaic complex. Geol. Mijnb. 46, 265-278.

Pettijohn, F. J. 1975: Sedimentary rocks, 3rd ed. New York, San Francisco, London: Harper \& Row.

Rosenkrantz, A. \& Pulvertaft, T. C. R. 1969: Cretaceous-Tertiary stratigraphy and tectonics in northern West Greenland. Mem. Am. Assoc. Petrol. Geol. 12, 883-898.

Schiener, E. J. 1974: Geological and Geophysical work between $69^{\circ} \mathrm{N}$ and $72^{\circ} \mathrm{N}$, central West Greenland. Rapp. Grønlands geol. Unders. 65, 23-26.

Selley, R. C. 1970: Ancient sedimentary environments. London: Chapman \& Hall.

Tröger, W. E. 1969: Optische Bestimmung der gesteinsbildenden Minerale, Teil 2, Textband. Stuttgart: Schweizerbart'sche Verlagsbuchhandlung.

van Veen, R. R. 1971: Depositional environments of the Eocene Mirador and Misoa Formations Maracaibo Basin, Venezuela. Geol. Mijnb. 50, 527-546.

Visher, G. S. 1965: Use of the vertical profile in environmental reconstruction. Bull. Am. Assoc. Petrol. Geol. 49, 41-61. 